\title{
A NEW PARADIGM IN RELIGIOUS DISCOURSE: Liberating Religion from the Shadow of Institutions, Organisations, and Religious Streams
}

\author{
By: Aksin Wijaya*
}

\begin{abstract}
Abstrak
Akhir-akhir ini, Indonesia diramaikan dengan tindakan kekerasan atas nama agama. Anehnya, pihak-pihak yang melakukan tindakan kekerasan berasal dari lembaga, organisasi, dan aliran keagamaan yang menuduh penganut aliran keagamaan lain sebagai sesat. Lebih aneh lagi, MUI yang selama ini menjadi eksekutor Tuhan, sama sekali tidak menfatwa sesat tindakan kekerasan yang dilakukan mereka yang mengatasnamakan agama. Peristiwa itu nampaknya tidak lepas dari klaim kepemilikan dan kebenaran atas nama agama yang dilakukan oleh sebagian mereka. Akibatnya, agama dijadikan justifikasi atau pembenaran tindakan kekerasan itu sendiri. Agama akhirnya berwajah kekerasan, bukan membawa kedamaian sebagaimana missi awal. Untuk melepaskan agama dari manipulasi mereka, dan dalam rangka melepaskan agama dari bayang-bayang dan klaim organisasi, aliran, dan lembaga keagamaan itulah, tulisan ini dibuat.

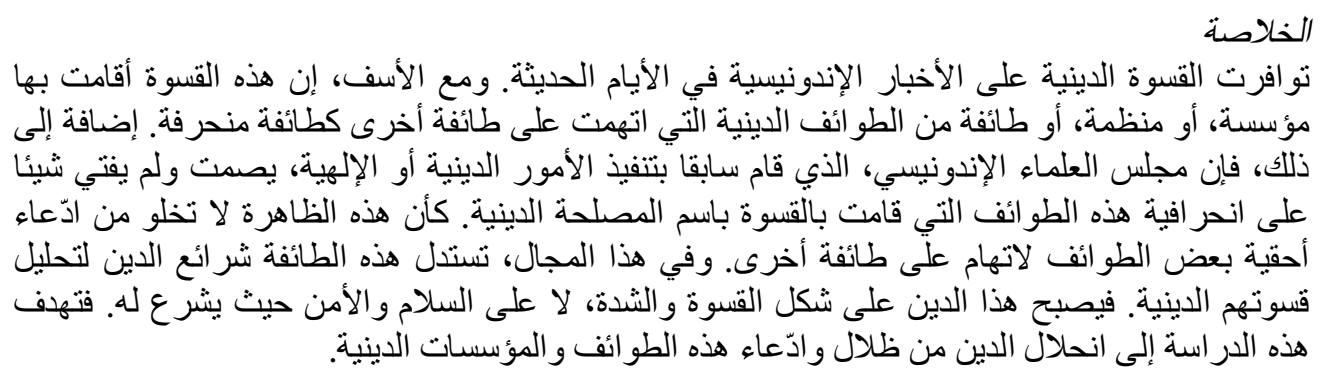

Keywords: Teosentris-Eskatologis; Antroposentris-Transformatif; dan Religiosentris.

\section{A. Introduction}

Current religious life of Indonesia is witnessing a number of interesting events including the issuance of fatwas by Majelis Ulama Indonesia (MUI) to condemn "deviated" groups such as Islam Liberal, Ahmadiyah, Al-Qur'an Suci (The Holy Quran), Al-Qiyadah al-Islamiyah, etc. It is ironic enough, however,

* The writer is a doctoral student at UIN Sunan Kalijaga, Yogyakarta; and lecturer at Ushuluddin STAIN Ponorogo, East Java. 
that no fatwas issued are related to terrors waged in the name of religion against the religious sects and followers of other religions, Jews and Christianity.

Modes of religious ideologies wrapped in fatwa and violence movements have caused religions, particularly Islam, to have no relative autonomy seen from spatial-temporal and dominant institutions and religious streams as well. Islam cannot be separated from the shadow of the past and Arab society. Neither can it be divorced from that of institutions, organisations and religious streams. Religion then becomes ossified, cannot communicate with local cultures and loses its liberating force. In its early emergence, Islam was living reality which was able to respond to problems its adherents were facing. It was able to free $\operatorname{God}^{1}$ and human $^{2}$ from hegemonic authority of pre-Islamic Arab culture and tribal mentality. ${ }^{3}$ In addition, Islam communicated with local cultures in which it was practised. $^{4}$

In contrast to the past, Islam of today has become powerless and its authority has been seized by the authority of Arab culture and dominant religious institutions. At the same time, non-Arab cultures, including Indonesian culture and individuals who are not affiliated to a certain dominant religious institution, have no authority in making dialogues with religion. The authorities of Arab culture and dominant institutions often feel obligated to defend religion from the influence of foreign cultures. Every understanding which is derived from nonArab traditions and is not from formal institutions would be considered wrong and deviated. Seen paradigmatically, religion often has a dialogical relationship with local cultures where Islam is practised.

\footnotetext{
${ }^{1}$ Pre-Islamic Arab society was polytheist, worshipping idols. In contrary, Islam offered monotheism as formulated in "There is no god but Allah".

${ }^{2}$ Humanism developed in pre-Islamic Arab was tribal humanism, not human humanism. See Montgomery Watt, Pengantar Studi Al-Qur'an, (Jakarta: PT. Raja Grafindo Persada, Rajawali Press, 1995), p. 12.

${ }^{3}$ This opinion does not go unchallenged. Khalil Abdul Karim, for instance. Puts forward that pre-Islamic Arabs had known civilisation so that the Quran took it and gave it new significance. See Khalil Abdul karim, Syari'ah: Sejarah Perkelahian Pemaknaan, trans. Kamran As'ad (Yogyakarta: LKiS, 2003); the negative image on pre-Islamic Arabs will disappear if it is seen from the Quranic perspective. See Thaha Husein, Fi al-Sŷ̂'ri al-Jâhili: al-Kitâb wa alQadiyah, (al-Qahirah: Ru'ya li al-Nasr wa Tawzi', 2007), pp. 78-86.

${ }^{4}$ Aksin Wijaya, Relasi Al-Qur'an dan Budaya Lokal: Sebuah Tatapan Epistemologis, Jurnal Pascasarjana UIN Sunan Kalijaga Yogyakarta: HERMENEIA, Vol. 4, No. 2, July-December 2005, pp. 235-254.
} 


\section{B. Paradigm of Understanding Islam}

Paradigmatic awareness above can be perceived from scientific paradigm as Thomas Kuhn has formulated. To Kuhn, the development of science does not run in a cumulative way as many thinkers believe, but in a revolutionary way. In the eyes of Kuhn, it is revolution that engenders changes and developments in science. Paradigmatic thinking

Logic of paradigmatic thinking offered by Kuhn is as follows:

Paradigm I $\rightarrow$ Normal science $\rightarrow$ Anomalies $\rightarrow$ Crisis $\rightarrow$ Paradigm II

According to Kuhn, at certain times science will become dominated by a certain paradigm. At the times, science runs normally. That is a period of accumulation of knowledge when scientists work and develop the influential paradigm. However, eventually scientists could not avoid contradictions and anomalies in the former old paradigm and, consequently, crisis could not be avoided as well. When the validity of the old paradigm is questioned, revolution could not cease to run. Thinkers are looking for a new paradigm they consider to be able to overcome problems which could not be solved by the old paradigm. And a big change takes place in science in that revolutionary period. ${ }^{5}$

In spite of various definitions on paradigm, the most common definition is the way to approach an object of investigation or a starting point to determine a point of view, formulating a theory, arranging questions and making a simple reflection of them. For Kuhn, paradigm is all systems of belief, values and techniques used altogether by a group of a certain scientists' community. ${ }^{6}$ While the paradigm concept as Kuhn offers is not definitive, Ritzer formulates it as a basic view concerning the subject matter of a science branch. Paradigm is useful to formulate what to learn, questions to answer, how to answer, and the rules to follow in interpreting gathered information so as to answer the problems in question. $^{7}$

${ }^{5}$ George Ritzer, Sosiologi Pengetahuan Berparadigma Ganda, terj. Alimandan, (Jakarta: Rajawali Press, cet ke V, 2004), p. 5. For further details, see Thomas S. Kuhn, The Structure of Scientific Revolutions: Peran Paradigma Dalam Revolusi Sains, terj. Cet. Ke 4 (Bandung: Rosda, 2002).

${ }^{6}$ George Ritzer, Sosiologi, p. 5.

${ }^{7}$ Ibid, p. 7. 
The technical formulation of Kuhn's paradigm model, according to Ritzer, includes four interrelated elements: exemplar, ${ }^{8}$ subject matter, theory and method. These elements play a significant role in determining scholars' scientific points of views concerning problems they are facing at certain periods. Therefore, change of periods will cause changes in paradigm.

One of the paradigms relevant for an argument is critical paradigm which combines plural and conflict paradigms. Critical paradigm is concerned about establishment and is always suspicious of common awareness and rationality hidden behind objective science. In the external reality of critical paradigm such a suspicion becomes common given that authorities often try to create and establish their hegemony. By contrast, it is uncommon if such an auto-critic is posed to the internal reality of the discourse structure of their thought as experienced by pioneers of critical paradigm in that they criticise each other.

From the above discussion, we can understand the role of certain discourses in enhancing their authority to control academic and Islamic discourses over times. Through critical paradigm, we learn to be suspicious of every uncommon control of scientific and Islamic dynamism. By doing so, we can also escape from that control and can freely read any scientific and Islamic phenomenon.

\section{Paradigmatic Modes of Understanding of Islam}

Seen from this paradigm, Islam serves to respond to problems facing certain cultures in which Islam is practiced. Thus, religious understanding at certain places and times depends on problems the umma are facing. The problem facing Muslim community in early times was related to who was the real God. After the long interaction and debates among thinkers, there had emerged theocentric and eschatological modes of thought. As soon as the reality changes, the problem Muslim community changes as well, viz. the problem of humanity such as human rights. Based on this problem, there had emerged an anthropocentric and transformative thought.

\footnotetext{
${ }^{8}$ Exemplar is the result of scientific finding which is publicly accepted. Ibid, p. 5.
} 


\section{Theo-centric-Eschatological Islam}

Pre-Islamic Arab community lived in their tribal tradition. Tribe became everything. Tribal forces had compelled individuals to obey the rules set up as sacred rules. One of the tribal regulations which were considered sacred is the worshipping of their conceived God. According to history, various existing tribes had their respective different gods. The number of gods reached 356 idols. With so many gods, pre-Islamic Arabs were polytheists. Taking this into consideration, the term God in its very general sense was applied. Each tribe had the names for their gods such as Lata, Uzza, Manat and so forth. It is said that at that time the word "Allah" was already known." This was the main problem Muhammad should cope with in his early mission.

Such dominant were the tribes in determining their members that Muhammad felt necessary to offer a new concept of God clandestinely so as to avoid the resistance from their chieftains. First of all, Muhammad called his family such as his wife, Khadijah, Ali b. Abu Talib and so on to recognize God. Not all of them accepted Muhammad's call. Abu Talib, his uncle, and Abu Jahal did not follow Muhammad's religion. ${ }^{10}$

Conceptually, God as offered by Muhammad is formulated in the sentence "there is no god but Allah". This formula supposes two things: negation and affirmation. Negation is declared to refute the general concept of God, for such a concept implies myriad gods. After the negation is declared, an affirmation is made by declaring that Allah is the only God. This is the concept of God's oneness accepted by Arab society. Eventually, Allah was accepted as the only God whom Muslims should worship. This is what was then called monotheism which was different from the pre-Islamic concept of Arab tribes.

After the death of Muhammad, Muslims of later generations still take theological issues as their central attention, in spite of their different emphases. In the time of Muhammad, attempts were made to declare the divinity of Allah and

\footnotetext{
${ }^{9}$ The term Allah was already familiar before the era of Muhammad. See Philip K. Hitti, History of the Arabs, terj. R. Cecep Lukman Yasir, (Jakarta: Serambi, 2005), pp. 126-127.

${ }^{10}$ Muhammad Abed al-Jabiri, al-Aql al-Assiyâsî̀ al-Arâbî: Muhaddadât wa Tajalliyât (Beirut: al-Markas al-Tsaqafi al-Arabi, cet. II, 1991), pp. 57-67.
} 
to refute other gods. However, after Muhammad died, the concept of "essence and oneness" of Allah was a conspicuous important theme. What do Allah and the One mean? Do they mean essence, attributes, or names? It is said that these questions were stirred up by the spread of the concept of God's dualism brought into Muslim community from non-Muslim traditions.

In response to this question, a number of schools of Islamic theology were established. The Ash'ariya and the Mu'tazila were among the most influential schools in the history of Islamic theology. Regardless of their different paradigms, both schools shared in their method of thinking, i.e. dialectical method. ${ }^{11}$ Through this method, they stood up for their respective teachings against foreign attacks either from Christian tradition or philosophy. They shared in their aim, i.e. to defend the glory of Allah, either his essence or attributes and names. In short, they defended Allah as the One in every sense. Allah is the only God whose existence is not caused by others. He is necessary being by himself (wajib al-wujud bi dhatih), while the others are possible being by others (mumkin al-wujud bi gayrihi). Allah is the centre of existence under which other existences exist. Thus, Islamic understanding prevailing at that time was theo-centric.

In addition to being theo-centric, classical Islam was more eschatological in orientation, prioritizing the hereafter life more that this mundane world. This ideology is based on the Quranic prescription that this "perishable world" is but a medium to go to the hereafter world. It is this hereafter world that is the real life.

Such a theo-centric and eschatological understanding of Islam does not contribute to solving the problems of the human existence in this world. It prioritizes the hereafter over the present world. This in turn affirms the slogan that the backwardness of Muslims is caused by their adherence to Islam, while other religious adherents gain progress since they leave their religions. ${ }^{12}$ This slogan

11 Ibnu Rusyd, Fasl al-Maqâl, Fima Baina al-Hikmah wa al-Syarî'ah Min al-Ittisâl, Dirasah wa tahkik: Muhammad Imarah, (Mesir: Dar al-Ma'arif, 1972), hal. 46; Yusuf Musa, Baina al-Dina wa al-Falsafah, Fi Ra'yi Ibnu Rusyd wa Falasifah al-'Asri al-Wasîth, (Mesir: Dar alMa' ârif, Cet. Ke II, 1968), hal. 93.

12 Muhammad Abed al-Jabiri, Isykaliyât al-Fikr al-Arâbî al-Muasyir (Beiru: Markaz Dirasat al-Wahdah al-Arabiyyah, 1989), pp.129-140. 
implies a call and a hope that Muslims would be able to reach progress as the West do.

The West have reached the peak of their progress, since their religious and worldly views are separated. Tolerance, freedom and democracy have become a consuming slogan. By contrast, this slogan is less significant for Muslims for they regard it secular. This is the conspicuous difference between the West and Muslims which should be taken into consideration. Why do not Muslims call for progress? Isn't it that progress will make our life free from oppression and give us our dignity?

In order for Muslims to get progress as the West do, the way to progress has to be opened. In this article I do not offer how to develop technology as the West did. Instead, I propose how to change our world view which is still theocentric and eschatological. This world-view would never change reality of Muslims' life, since it disregards the importance of the present world. This does not mean that Muslims should look down the importance of eschatological aspects of Islamic teachings. By contrast, it has to be emphasized that this world is one of the necessary prerequisites of obtaining the happiness in the hereafter life. Our belief in the hereafter should not make us ignore the importance of this world. Our achievements in this world would impact on our hereafter life.

Thus, the future meant in this conception is not the hereafter life, but it is our future and the future of the next generation in this world. The Quran has warned us that we should not leave our children in starvation. To realise this, however, Indonesian Muslims do not necessarily have to do KB (Keluarga Berencana or Family Planning). Instead, it can be realised by improving skills and creativity. Belief in the hereafter life should motivate us to do the best in this world.

\section{Anthropocentric-Transformative Islam}

This understanding of Islam will be a sustainable paradigm of Islamic thought. Even it will be relevant forever. Since their defeat by Israel in 1976, Arab society, often regarded to have the authoritative understanding of Islam was aware 
of their failure to deal with tradition and modernity. ${ }^{13}$ Arab thinkers started to question the validity of the dominant theo-centric and eschatological paradigm of Islamic thought. They looked for a new paradigm which would be able to solve contemporary problems they were facing.

One of the compelling problems we are facing is that of humanity. "God in the present time needs no defence". ${ }^{14}$ In contrast, "it is human who needs defence", so that Muslim societies will not be underdeveloped. According to them, the failure of Muslim societies is because they still stick to the old paradigm so that they look for the ideal Islam in the past which ever reached the golden victory. ${ }^{15}$ In face of modernity, they feel it unnecessary to refer to the old paradigm which is outdated and even its validity in solving contemporary problems starts to be questioned.

At the same time, they prefer to use a new paradigm in replace of the old one. ${ }^{16}$ Hassan Hanafi clearly uses new terms which he regards more deconstructive. For instance, he offers the terms like from text to reality, from God to human, and so forth. From this counter-discourse, Hanafi tries to establish an anthropo-centric paradigm which underlines the importance of human as the centre of existence. In this paradigm, human is regarded as the real goal of Islamic teaching. An interpretation of Islam should be aimed at the liberation of human from the dominant old paradigm which undermines human for the sake of God' absolute authority.

The anthropocentric paradigm of Islam has created various Islamic discourses centring on human such as theology of liberation, progressive Islam,

\footnotetext{
${ }^{13}$ Ibid., p. 55

${ }^{14}$ In Indonesia this was stated by Gus Dur. See, Abdurrahman Wahid, Tuhan Tidak Perlu Dibela (Yogyakarta: LKiS, 2000).

${ }^{15}$ Issa J. Boullota, Dekonstruksi Tradisi, Gelegar Pemikiran Arab Islam (Yogyakarta: LKiS, 2002), pp, 4-10.

${ }^{16}$ Boulatta puts forward three three discourses in Contemporary Arab world in response to the problem of tradition and modernity: transformative discourse, reformative discourse, and ideal-totalistic discourse. See further Issa J. Boullota, Dekonstruksi Tradisi, Gelegar Pemikiran Arab Islam (Yogyakarta: LkiS, 2002), p. 4. Also Hassan Hanafi, Turas dan Tajdid: Sikap Kita terhadap Tuiras Klasik (Yogyakarta: Titian Ilahi Press dan Pesantren Pasca sarjana Press, 2001), p. 32.
} 
transformative Islam, actual Islam, and so forth. In this paradigm, human becomes a real targeted aim of Islamic teaching.

By describing the development of religious discourse in the Arab world, I intend to take an analogous lesson ( $i$ 'tibari) for a mode of Islamic understanding in Indonesia. This is because Islamic understanding developed in Indonesia reflects the Islamic model as developed in Arab. ${ }^{17}$

Anthropocentric Islam is a basis for the understanding of Indonesian Islam, that is, an understanding which is accepted by Indonesian people and can move their live, as Protestantism moved its community to develop a rational thinking in observing the command of God. Such an Islamic understanding can be termed as transformative Islam, an understanding which emphasizes the need to transform Islamic teachings into the real life.

This mode of Islamic understanding includes three interrelated aspects: God, nature and human. God is placed in the highest level of existence, nature as God's creation and human as the actors of the messages of God's moral and legalislation as stated in the Quran. Different from theo-centric and eschatologic paradigm, the transformative Islam places God as the prime mover of human to implement God's messages on moral and legislation in this world, not as the executor of God's messages as claimed by the advocates of theo-centric and eschatological Islam. The anthropo-centric and transformative Islam lets God be the only executor in the hereafter. Human only implements the messages of God's moral and legislation to keep nature balanced as His creation and to realise the harmony and prosperity among humankind.

In anthropocentric and transformative Islam, the prophet is understood not as the holder of all authority over human, but as uswatun hasanah (exemplary model) for humankind in their life. As human should keep nature balanced. They should work for their lives and do not oppress the other religious adherents. Did Muhammad say: "[the real] Muslim is one who saves the others by his hands and tongue"'?

${ }^{17}$ Details on this can be found in Aksin Wijaya, Menggugat Otentisitas Wahyu Tuhan: Kritik Atas Nalar Tafsir Gender (Yogyakarta: Safiria Insania Press, 2004), pp. 94-106. 
This hadith teaches Muslims to be the first to keep balance of nature and to liberate human from oppression and backwardness. How could we save the others while we do nothing to illegal logging, poverty, and social conflicts? In this regard, all of us should participate in keeping that balance.

3. Religio-centric Islam: authonomizing religion and developing Individual Based Religious Discourses.

In line with the complexity of the problems of humanity, the other compelling problem drawing our high attention comes to the fore concerning religion itself. So far, religion has been regarded as a place to solve theological as well as human problems. However, the religion itself creates its own problems. The religion will never be able to solve the theological and human problems as far as it cannot liberate itself from the problems it faces. This is important to be emphasized since MUI, NU and Muhammadiyyah, have controlled and dominated religious authority and autonomy as an objective reality open to every one.

What I call "religio-centric Islam" is that religion becomes an autonomic objective reality and a centre of existence under which other existences could establish. Religion should not be controlled by any power except of itself. Every one has the right to understand it.

The problem is how religion could be an independent objective reality so that it can present itself to its umma at all places and times. They become individually free to understand and practise their religion without being fear of any control imposed by institutions such as MUI, NU and Muhammadiyah. By doing so, individual-based Islamic discourse will emerge.

a) Religion: Absolute God's authority versus the authority of Institutions, Organisation and Religious streams

To make religion as an objective independent and autonomic reality, we should understand the essence of religion itself. By doing so, we can place its objective and autonomic existence properly. Religion is God's legislation sent down to the world as His creation. It is meant to guide humankind to the straight 
path to the happiness in the hereafter. Religion is under the absolute authority of God.

However, God gives no direct guide, but he has chosen Muhammad as His 'deputy' in this world. As God's deputy, Muhammad has the 'semi-absolute' authority over the Quran as the basic source of Islam. His main task is just to "deliver" and "explain" God's messages to Muslims, not to create a new thing or even to limit religious messages to his own understanding.

Placed in the real social context, God's messages interacted with tribes, states, and social religious institutions and organisations which infrequently caused. Muhammad made use of state and tribes as a medium of spreading Islam over various regions. The establishment of the Medinan state, for instance, was part of his strategies to do his religious mission. This was the case of Muhammad's demand for trusting Islamic leadership to the Quraish tribe. It is said that he said: "A leader should be [chosen] from the Quraish tribe". ${ }^{18}$

It should be underlined however that although under the power of a state like Madinah, Islam was actually still under the authority and control of Muhammad as an individual to the point that Islam could have easily spread all over the world. Under the leadership of Muhammad, religion was free to communicate its individual followers, and they had a free responsible access to understand it. Religious dependence on states, religious institutions and organisation occurred after the death of Muhammad. Religion then was interfered with political affairs.

Religion had become an effective tool for those who desire to get a political legitimacy from a certain religious community. This can be seen in the case of the leadership of Muawiyyah which used the concept and ideology of "Jabariyyah" and, in most cases, in the fatwas issued by MUI in the Indonesian context. In addition, religion is often arbitrarily controlled by an ideology and a culture hidden behind institutions, organisations and religious streams. Violence is

18 Jamal al-Banna, Runtuhnya Negara Madinah: Islam Kemasyarakatan versus Kenegaraan, trans. Jumadi Sunardi (Yogyakarta: Pilar Media, 2003), pp. 114-116; Ameer Ali, Api Islam: sejarah Revolusi dan Cira-cita Islam dengan Riwayat Hidup Nabi Muhammad SAW, trans. HB. Yasin (Jakarta: Pustaka Firdaus, 1978), pp. 92-103. 
done in the name of religion, and God is pictured as the violent. This phenomenon can be seen in violence occurred in many parts of the Muslim world and spread by a number of Muslim organizations such as Hizbullah, Hamas, Al-Qaeda and Jamaah Islamiyah (JI). In Indonesia, we can find mass organisations such as FPI (Fron Pembela Islam, Front for Defenders of Islam) and Laskar Ahlussunnah. They are indifferent with God's message that Muhammad should use wise ways of delivering the message. The Quran says: "Call unto the way of thy Lord with wisdom and fair exhortation, and reason with them in the better way." (Q. AlNahl [16]: 125). ${ }^{19}$ They neglect the fact that Muhammad emphasized the importance of knowledge in solving problems they face. A saying attributed to him tells us: "seek knowledge even to China". Muhammad once criticised a farmer of following him in matters of farm. He said, "You know better than me about worldly affairs". Thus, Muhammad regarded religion only as "one of the alternatives" to solve various problems, without neglecting the other possible alternatives. Poverty problem can only be solved by economic science, political problem by political science, legal problem by law science, theological and moral problems by religion.

Islam's acceptance of other alternatives can be seen from the Quranic statement that religion does not force its adherents to follow its messages without any free choice. The Quran says: "there is no compulsion in religion. The right direction is henceforth distinct from error" (Q. al-Baqarah [2]: 256). It also says: "unto you your religion, and unto me my religion" (Q. al-Kafirun [109]: 6).

In addition to the necessary understanding of the essence of religion, the need to liberate religion from the shadow of the authority and control of institutions, organisations and religious streams stems from the assumption that these institutions, organisations and religious streams have latent ideologies hidden behind the objectivity of reason and discourse which will control individuals. In the end, people's mode of thought cannot be divorced from any

\footnotetext{
${ }^{19}$ Translator's note: All Quranic translation in this article follow Marmaduke Pickthall's The Meaning of The Glorious Koran: An Explanatory Translation (New York: Alfred 'A' Knopf, 1930).
} 
ideology or culture of a certain social community in which it emerges. ${ }^{20}$ Individuals are under the control of organized institutions, organisations and groups, since a society, according to Durkheim, ${ }^{21}$ is an independent objective entity which has its own conscience different from that of individuals involved within it. When both consciences are conflicting, society's conscience will win and get rid of individuals.

Indonesian society, for instance, cannot escape from rules and systems set up by the government in the form of Pancasila ideology. Members of the Nahlatul Ulama (NU) cannot avoid norms and systems of thought constructed within its doctrine of Ahlussunnah wal Jamaah (Aswaja). Neither can members of Muhammadiyah escape from the system of thought constructed by Majlis Tarjih. Nor can members of Hizbut Tahrir be free from its ideology of khilafat. As a consequence, social communication only occurs in a certain social organisation where they live. This is what is called in the sociological term as a "group reference". ${ }^{22}$ Social discourses are also limited to discourses selected by institutions, organisations, and groups. This is what is called "normative reference". Group reference is a social communication which binds its members and becomes reference by individuals involved within it to understand situations and conditions surrounding it or actual problems prevailing in a wider scale such as national problems.

In other words, an individual's opinion is product of his participation in social life which becomes reference for his group. One's individual opinion concerning a certain situation or a scholarly discourse depends on how his group reference understands it; and how he is influenced by his perception of how his group reference looks at a certain problem.

${ }^{20}$ According to Popper, analyzing sociology of knowledge, every thinking never comes from vacuum, since every one cannot escape from what is called total ideology, yang berada dilingkungan habitat sosialnya.Karl Poper, Masyarakat Terbuka dan Musuh-musuhnya, (Yogyakarta: Pustaka Pelajar, 2001), hal. 59; Karl Mannheim, Ideologi dan Utopia: Menyingkap Kaitan Pikiran dan Politik, terj. F. Budi Hardiman, (Yogyakarta: Kanisius, cet. 2, 1993), hal. 287.

21 David Berry, Pokok-pokok Pikiran dalam Sosiologi, trans. Paulus Wirutomo, 3rd impression (Jakarta: PT. Rajawali, 1974), p. 83.

${ }^{22}$ Ibid. p. 83. 
b) Objectification of religion: Freeing religion from the shadow of institutions, organisations and religious streams.

How to liberate religion from the shadow of the authority and control of institutions, organisations and religious streams? An attempt should be stated by the reconstruction of reason and discourse $\mathrm{e}^{23}$. The way of reasoning determines the essence of a discourse.

Seen from claims and implications prevailing so far, method of religious reason seems to romantic-objective. This method aims at the objective search for meaning intended by its author. ${ }^{24}$ Such a method of reading presupposes that a reader can equate his position with the author. ${ }^{25}$ As if he were the shadow of the author. As a consequence, the reader tends to regard his understanding as true and representative of the intention of the author.

In religious discourses, many claim that they have understood the real and objective God's messages, and, therefore, they claim to have the authority over the interpretation of religion. A certain religious discourse produced by a certain organisation, institution and religious streams is often regarded as purely epistemological. That discourse is believed to objectively originate from the Quran, completed with the method set up also by the Quran.

It should be noted that such a scientific objectivity has made the hegemony of ideology and culture of a certain community fortify. This is because an objective expression often sounds compelling, especially if backed up by a number of intellectual authorities as gathered within the fatwa commission of MUI, Bahtsul Masail of NU and Majelis Tarjih of the Muhammadiyah.

\footnotetext{
${ }^{23}$ I deliberately distinguish mind from discourse by following al-Jabiri. Al-Jabiri divides thought into two: content and device. As content, thought is a set of opinions and thinking produced by thought as tool, for example, thought about ethics, doctrines of Islamic schools of law, or thought on human world view concerning nature. As device, it is a thinking method of producing knowledges. See Muhmmad Abed al-Jabiri, Iskaliyat., pp. 51-52. Also, Muhmmad Abed al-Jabiri, Takwîn al-Aqli al-Arabi (Beirut: Al-Markaz Al-Tsaqafi al-Arabi Li-Al-Thaba'ah wa al-Nasr wa al-Tauzi', Cet; ke IV, 1991), p. 11-12; see also Cliffort Geertz, Pengetahuan Lokal (Yogyakarta: Rumah Penerbitan, 2003), p. 221.

${ }^{24}$ See Nasr Hamid Abu Zaid, Al-Qur'an, Hermeneutika dan Kekuasaan, Bandung: RQiS, 2003, hal. 42-46. Also, Paul Ricoeur, Hermeneutika Ilmu Sosial, terj. Muhammad Syukri, Yogyakarta: Kreasi Wacana, 2006, pp. 60-63.

${ }^{25}$ This reading method will de-legitimize the authority of language as a determinant of meaning. Muhammad 'Ata Al-sid, Sejarah Kalam Tuhan, trans. Ilham B. Saenong (Jakarta: Teraju, 2004), p.14.
} 
From the romantic-objective hermeneutic ${ }^{26}$ perspective, an objective understanding as claimed by religious institutions such as MUI, NU and Muhammadiyah will be established if the intellectual community is involved in attempts to read into the world of its writer.

In the eyes of Gadamer, ${ }^{27}$ this aim will never be reached because it is impossible to go into the world of the writer. Even the writer himself cannot do so with what he have written and told. This is because the situation when he was writing and telling passed and it is likely that he have forgot. Reading and understanding something cannot be divorced from subjectivity, for the reader lives in circumstances and contexts which are often different from the writer. The reader is always related to a certain historical situation. ${ }^{28}$ Every one is influenced by situations where he lives. Situations and conditions are normative as presumptions Gadamer calls "historical conditionality" of the reader. From this perspective, each individual has the authority to determine his understanding of concepts, including the concept of God.

In line with this, a distinction should be made between religion and religious discourse. Religion is God's legislation, while religious discourse is its interpretation either by Muhammad, his Companions or mujtahid as reflected in various Islamic disciplines such as fiqh, kalam, and tasawwuf. As a God's legislation, religion is not bound by times and places. It is free to be understood by its followers at all places and times. By contrast, religious discourse is always tied by places and times, for it is the result of human interpretation which is relative.

Religious discourse is produced by a certain mujtahid at a certain place and time. Thus, it is only relevant for spatio-temporal conditions in which it is produced or for the similar conditions. The Shafi' $i$ fiqh, for instance, was applied

\footnotetext{
${ }^{26}$ On hermeneutics, see Komaruddin Hidayat, Memahami Bahasa Agama: Sebuah Kajian Hermeneutika, (Jakarta: Paramadina, 1996), p. 126.

27 Richart King, Agama, Orientalisme Dan Postkolonialisme, Sebuah Kajian Tentang Pertelingkuhanantara Rasionalitas dan Mistik, Yogjakarta: Qalam, 2001, hal. 140; Stephen Palmquis, Pohon Filsafat, (Yogyakarta: Pustaka Pelajar, 2002), hal. 229.

${ }^{28}$ Quoting Heidegger, Gadamer states that every understanding procees is always related to pre-structures. See Poesporadjo, Interpretasi, (Bandung: Remaja Karya CV, 1987), hal. 96.
} 
specifically to the time and place in which al-Shafi'i lived or to the similar time and place. The case is also of the Hanafi, Maliki, and Hanbali.

Religious institutions, organisations and streams have misunderstood about this difference. They do not differentiate between religion and religious discourse. ${ }^{29}$ They hold only one religion which is under the absolute authority of God. As a consequence, they consider the fiqh of the Shafi' ${ }^{\prime}$, Hanafi, Maliki and Hanbali, the theology of the Ash'ari, Maturidi, Mu'tazilah, and the Islamic mysticism of al-Ghazali, al-Junaydi, 'Abd al-Qadir al-Jilani, and so forth as religion itself. Just like religion, religious discourses produced by mujtahids are claimed to be religion which is not tied by times and places.

In addition to liberating religion from the shadow of religious institutions, organisations and streams, religion itself stimulates the emergence of myriad religious discourses which are relevant for the spatio-temporal context of its individual as well as collective readers. But nevertheless, it could not be neglected that religious discourse is frequently separated from what religion is meant by its author. According to Paul Riceour, when a discourse is put into a writing, what happens is actually a maintenance of "meaning of discourse", not "event of discourse" itself. ${ }^{30}$ Here, a text becomes autonomous of threefold: of the intent of its author; of its original socio-historical context; and of its first targeted audiences. Thus, the text becomes an objective thing.

Any interpreter has to be aware of this textual autonomy, including religious texts. Due to this textual autonomy, which according to Ricoeur is a constitutive character of the textuality of a text, the text becomes open to any reading and is not subjected to any attempts to fix and monopolize its meaning. As soon as it is written, any text constitutes its own meaning which is not always

\footnotetext{
${ }^{29}$ On the difference between religion and religious discourse, see Nasr Hamid Abu Zaid, Naqd al-Khitâb al-Dîni, 2nd edition (Mesir: Sina Li-al-Nasr).

${ }^{30}$ Paul Ricouer, Hermeneutics and The Human Sciences, John B. Thompson, ed. \& trans. (London-New York: Cambridge of University Press, 1982), p. 145; Ignas Kleden, "Pemberontakan terhadap "Narasi Besar": membaca teks Putu Wijaya dengan pendekatan tekstual" in Bahasa dan Kekuasaan: Politik Wacana Di Panggung Orde Baru (Bandung: Mizan, 2rd edition, 1996), p. 327.
} 
equal to the original intention of its author. ${ }^{31}$ Therefore, a text can be decontextualized from its historical situation on the one hand, and at the same time it can be recontextualized within its new situation and new audiences on the other. ${ }^{32}$ Its new meanings thus can be reproduced according to its new targeted groups. $^{33}$

Thus, in fact there is no compulsion for everyone to individually follow religious discourses produced by certain religious institutions, organisations and religious streams. Everyone has the change to approach religion and formulate religious discourses relevant to his spatio-temporal context. By doing so, religion becomes an object from which everyone can get solutions to his/her problems. In this regard it is significant to consider five moral principles that Khaled Abou Fadl offers, including trustfulness, comprehensiveness, rigorousness, and selfcontrol. $^{34}$ In addition, we might consider the concept of epistemological presupposition $^{35}$ and exclusionary reasons. ${ }^{36}$ These three principles can be norms upon which one bases his following a particular opinion. It can be determined if he will follow other's opinion who has "epistemological presupposition" or not. If so, does he/she follow by free choices through "exclusionary reasons". If by free choices, it means that he refutes coercion on him/her. Otherwise, it means he/she serves as the follower of the followed.

If religion can be freed from the shadow of religious institutions, organisations and streams, each individual can freely formulate individual-based religious discourses. And that means that religious discourses are produced by individuals as mujtahid.

\footnotetext{
${ }^{31}$ Paul Ricouer, as quoted by Kleden, makes a clear-cut distinction between the intention of speakers and the meaning of speech. The former is intentional and understanding upon it depends on what readers understand about speakers' subjectivity. The latter is propositional and understanding upon it depends on the relation between subjects and predicates within it. Ignas Kleden, "Pemberontakan terhadap "Narasi Besar", p. 327.

32 Ibid., p. 328.

${ }^{33}$ Paul Ricouer Hermeneutics., p. 91.

${ }^{34}$ Khaled Abou El Fadl, Speaking in God's Name: Islamic Law, Authority and Women (England: Oneworld Oxford, 2003), pp. 53-56.

${ }^{35}$ Ibid., p. 19.

${ }^{36}$ Ibid., p. 22.
} 
Each individual is given the authority to independently produce religious discourses through a particular preferred approach without being tied with institutions to which the majority are affiliated. It is this religion produced by individuals that Muslims should develop so that they will be able to solve their own problems. And Islam is the main source through which they improve their spirituality.

\section{Conclusion}

Institutions, organisations and religious sects have subdued the independence and autonomy of religion. In the above discussion, I have attempted to free religion from the shadow of that authority. I believe that only by doing so that Muslims have free access to the understanding of Islam from many perspectives and points of view.

The aim of this article is to let religion speak about itself to its umma. In addition, it is hoped that every individual is able to make a dialogic relationship with religion.

\section{BIBLIOGRAPHY}

2003. Al-Qur'an, Hermeneutika dan Kekuasaan, Bandung: RQiS.

Ali, Syed Ameer. 1978. Api Islam: Sejarah Revolusi dan Cira-cita Islam dengan riwayat Hidup Nabi Muhammad SAW, translated by HB. Yasin, Jakarta: Pustaka Firdaus.

Al-Banna, Jamal. 2003. Runtuhnya Negara Madinah: Islam Kemasyarakatan versus Kenegaraan, translated by Jumadi Sunardi, Yogyakarta: Pilar Media.

Berry, David. 1974. Pokok-pokok Pikiran dalam Sosiologi, translated by Paulus Wirutomo, $3^{\text {rd }}$ edition, Jakarta: PT. Rajawali.

Bleicher, Yoseph. 1980. Contemporary Hermeneutics: Hermeneutics as Method, Philosophy and Critique, London: Raoutledge \& Kegan Paul.

Boullota, Issa J. 2002. Dekonstruksi Tradisi, Gelegar Pemikiran Arab Islam, Yogyakarta: LkiS.

El Fadl, Khaled Abou. 2003. Speaking In God's Name: Islamic Law, Authority and Women, England: Oneworld Oxford. 
Geertz, Cliffort. 2003. Pengetahuan Lokal, Yogyakarta: Rumah Penerbitan.

Hidayat, Komaruddin. 1996. Memahami Bahasa Agama: Sebuah Kajian Hermeneutika, Jakarta: Paramadina.

Hitti, Philip K. 2005. History of the Arabs, translated by R. Cecep Lukman Yasur, Jakarta: Serambi.

Hanafi, Hassan. 2001. Turas dan Tajdid: Sikap Kita terhadap Turas Klasik, Yogyakarta: Titian Ilahi Press dan Pesantren Pascasarjana Press.

Husein, Thaha. 2007. Fi al-Syı̂'ri al-Jâhili: al-Kitâb wa al-Qadiyah, Cairo: Ru'ya li al-Nasr wa Tawzi'.

Izutsu, Toshihiko. 1997. Relasi Tuhan dan Manusia, translated by Agus Fari Husein, Yogyakarta: Tiara Wacana.

al-Jabiri, Muhammad Abed. 1991. al-Aql al-Assiyasi al-Arâbi: Muhaddadât wa Tajâlliyât, $2^{\text {nd }}$ edition, Beirut: al-Markas al-Tsaqafi al-Arabi.

. 1989. Isykâliyat al-Fikr al-Arâbi al-Muâsyir, Beirut: Markaz Dirasat alWahdah al-Arabiyyah.

. 1991. Takwîn al-Aqli al-Arabi, $4^{\text {th }}$ edition, Beirut: Al-Markaz Al-Tsaqafi al-Arabi Li-Al-Thaba' ah wa al-Nasr wa al-Tawzi'.

Karim, Khalil Abdul. 2003. Syari'ah: Sejarah Perkelahian Pemaknaan, translated by Kamran As'ad, Yogyakarta: LkiS.

King, Richart. 2001. Agama, Orientalisme Dan Postkolonialisme, Sebuah Kajian Tentang Pertelingkuhan antara Rasionalitas dan Mistik, Yogjakarta: Qalam.

Kleden, Ignas. 1996. "Pemberontakan terhadap "Narasi Besar": Membaca teks Putu Wijaya dengan Pendekatan Tekstual" in Bahasa dan Kekuasaan: Politik Wacana Di Panggung Orde Baru. Bandung, Mizan.

Kuhn, Thomas S. 2002. The Structure of Scientific Revolutions: Peran Paradigma Dalam Revolusi Sains, $4^{\text {th }}$ edition, Bandung: Rosda.

Mannheim, Karl. 1993. Ideologi dan Utopia: Menyingkap Kaitan Pikiran dan Politik, translated by F. Budi Hardiman, Yogyakarta: Kanisius.

Montgomery Watt. 1995. Pengantar Studi Al-Qur'an, Jakarta: PT. Raja Grafindo Persada, Rajawali Press.

Musa, Muhammad Yusuf. 1968. Baina al-Dîn wa al-Falsafah, Fi Ra'yi Ibnu Rusyd wa Falâsifah al-Asri al-Wasîth, Egypt: Dar al-Ma'arif.

Palmquis, Stephen. 2002. Pohon Filsafat, Yogyakarta: Pustaka Pelajar.

Poesporadjo. 1987. Interpretasi, Bandung: Remaja Karya.

Popper, Karl. 2001. Masyarakat Terbuka dan Musuh-musuhnya, Yogyakarta: Pustaka Pelajar. 
Ricouer, Paul. 1982. Hermeneutics and The Human Sciences, John B. Thompson, ed. \& terj., London-New York: Cambridge of University Press.

.2002. Filsafat Wacana: Membelah Makna dalam Anatomi Bahasa, Yogyakarta: IRCISOD.

Ritzer, George. 2004. Sosiologi Pengetahuan Berparadigma Ganda, translated by Alimandan, Jakarta: Rajawali Press.

Rusyd, Ibnu. 1972. Fasl al-Maqâl, Fîma Baina al-Hikmah wa al-Syari'ah Min alIttishâl, Dirasah wa tahkik: Muhammad Imarah, Egypt: Dar al-Ma'arif.

Al-Sid, Muhammad 'Ata. 2004. Sejarah Kalam Tuhan, translated by Ilham B. Saenong, Jakarta: Teraju.

Wahid, Abdurrahman. 2000. Tuhan Tidak Perlu Dibela, Yogyakarta: LkiS.

Wijaya, Aksin. 2004. Menggugat Otentisitas Wahyu Tuhan: Kritik Atas Nalar Tafsir Gender, Yogyakarta: Safiria Insania Press.

2005. Relasi Al-Qur'an dan Budaya Lokal: Sebuah Tatapan Epistemologis, Hermeneia (Journal of Postgrduate Program of UIN Sunan Kalijaga Yogyakarta), Vol. 4, No. 2, July-December.

Zaid, Nasr Hamid Abu. 1993. Naqd al-Khitâb al-Dîni, $2^{\text {nd }}$ edition, Egypt: Sina Lial-Nasr. 